\title{
FACTORS ASSOCIATED WITH THE DEPRESSION, ANXIETY AND STRESS AMONG HIGH MEDICAL SCHOOL OF PROFESSIONAL STUDIES STUDENTS
}

\author{
Vesna R. Jovanovićl, Nela Đonović2,3, Aleksandra Dutina ${ }^{4}$ \\ ${ }^{1}$ High Medical School of Professional Studies, Belgrade, Serbia \\ ${ }^{2}$ University of Kragujevac, Serbia, Faculty of Medical Sciences \\ 3 Institute for Public Health, Kragujevac, Serbia \\ ${ }^{4}$ Clinic for Mental Disorders "Dr Laza Lazarevic", Belgrade, Serbia
}

\section{FAKTORI POVEZANI SA DEPRESIVNOŠĆU, ANKSIOZNOŠĆU I STRESOM KOD STUDENATA VISOKE ZDRAVSTVENE ŠKOLE STRUKOVNIH STUDIJA}

\author{
Vesna R. Jovanovićl ${ }^{\text {, Nela Đonović2,3, Aleksandra Dutina }}{ }^{4}$ \\ IVisoka zdravstvena škola strukovnih studija, Beograd \\ ${ }^{2}$ Univerzitet u Kragujevcu, Srbija, Fakultet medicinskih nauka \\ 3Institut za javno zdravlje, Kragujevac \\ ${ }^{4}$ Klinika za psihijatrijske bolesti „Dr Laza Lazarević“, Beograd
}

\begin{abstract}
Objective. Objective of this research was to examine which factors were related to depression, anxiety and stress among nurses/technicians, professional studies students.

Methods. A cross-sectional study was conducted among students of the High Medical School of Professional Studies in Belgrade. The sample consisted of 535 students of all three years, between 18 and 56 years of age. Depression, Anxiety and Stress Scale (DASS - 42) was used in the research, as well as a questionnaire on personal information which included data on personal impression regarding the importance of exam marks and the feeling of satisfaction with the self as a student.

Results. The results of the study showed that $13.6 \%$ of the examined student population had symptoms of depression, $25.6 \%$ had symptoms of anxiety and $26 \%$ had symptoms of stress, which were varying from mild to extremely showing. Average values for all three inspected scales (depression, anxiety, stress) were statistically significantly different depending on the gender of the participants ( $p=0.020 ; p=$ $0.001 ; p=0.001)$, employment status $(p=0.007 ; p=0.020$; $p=0.005)$, total years of service $(p=0.049 ; p=0.051 ; p=$ 0.017 ) and feeling of satisfaction with the self as a student ( $p$ $=0.000 ; p=0.021 ; p=0.004)$. There was a statistically significant difference in average values of the stress scale with respect to the motive to enroll the school $(F=6.445 ; p<0.05)$. Average values of the stress scale were the highest with the participants whose motive was to secure a work position and the lowest with the participants whose motive was promotion in their profession.

Conclusion. The results of the research point out the importance of early detection of mental health problems, aiming to find and develop adequate prevention and promotion of programs directed towards improvement of mental health and quality of life.
\end{abstract}

Key words: students, depression, anxiety, mental health

\section{SAŽETAK}

Cilj. Cilj ovog istraživanja bio je da se ispita koji su faktori povezani sa depresivnošću, anksioznošću i stresom kod medicinskih sestara/tehničara, studenata strukovnih studija.

Metode. Sprovedena je studija preseka među studentima Visoke zdravstvene škole strukovnih studija u Beogradu. U uzorak je uključeno 535 studenata sve tri godine studija, starosti od 18 do 56 godina. U istraživanju je korišćena skala za procenu depresivnosti, anksioznosti $i$ stresa (DASS-42) $i$ upitnik o ličnim podacima, koji je obuhvatio $i$ podatke o subjektivnom doživljaju važnosti ocene na ispitu i osećaju zadovoljstva sobom kao studentom.

Rezultati. Rezultati studije pokazali su da 13,6\% ispitivane studentske populacije ima simptome depresije, 25,6\% simptome anksioznosti i 26\% simptome stresa, koji su se kretali u rasponu od blago do vrlo jako izraženih. Prosečne vrednosti sve tri posmatrane skale (depresivnost, anksioznost $i$ stres) razlikovale su se statistički visoko značajno u zavisnosti od pola ispitanika $(p=0,020 ; p=$ $0,001 ; p=0,001)$, radnog statusa $(p=0,007 ; p=0,020 ; p$ $=0,005)$, ukupan radni staž $(p=0,049 ; p=0,051 ; p=$ $0,017)$, zatim osećaja zadovoljstva sobom kao studentom ( $p$ $=0,000 ; p=0,021 ; \quad p=0,004)$. Postojala je statistički značajna razlika u prosečnim vrednostima stres skale $u$ odnosu na motiv za upis u školu $(F=6,445$; $p<0,05)$. Prosečne vrednosti stres skale bile su najveće kod ispitanika čiji je motiv bio obezbeđenje radnog mesta, a najniže kod ispitanika čiji je motiv bio napredovanje u struci.

Zaključak. Rezultati istraživanja ukazuju na značaj ranog sagledavanja problema mentalnog zdravlja radi iznalaženja $i$ razvijanja adekvatnih programa prevencije $i$ promocije usmerenih ka unapređenju mentalnog zdravlja $i$ kvaliteta života.

Ključne reči: studenti, depresija, anksioznost, mentalno zdravlje 


\section{INTRODUCTION}

Problems of mental health are nowadays a subject to numerous studies precisely due to high prevalence of metal disorders, long treatments and significant decrease of quality of life of the patients (1). These problems most often appear for the first time during childhood and adolescence (2) which points out the importance of early understanding of risk factors for the onset of mental disorders among the young. Research in our environment show that one third of secondary school population expresses signs of psychological suffering and mental problems, and similar data have been obtained also for the student population1. The most common mental problems among students are depression, anxiety and stress (3). Research confirm that medical and health care students are under higher risk of mental disorders development comparing to their colleagues from other academic areas precisely due to their exposure to increased emotional pressures arising from facing various human sufferings (4).

For nursing students, the beginning of their clinical practice is the most important stress period in their education process (5). As the most common reasons for increase of stress related to education in nursing profession the following are stated: encounter with pain and suffering, interpersonal problems with clinical teachers, gap between theory and practice, lack of readiness to act in practice and fear of making a mistake5. Stressful events during the educational process of nursing students negatively influence their academic, professional and personal life (6). The research point out that there is a negative correlation between stress level on one side and professional knowledge and skills on the other which consequently influences adequate care and concern for patients (7).

Some research point out that depression, anxiety and stress symptoms are more common among female nurses than among male participants (8), as well as that these symptoms are more frequent among persons with longer period of service8. In the research on the frequency of depression, anxiety and stress among nurse students in Thessaloniki, it has been stated that $52.4 \%$ of the participants have had symptoms of depression, as well as that there has been no difference in terms of stress and depression frequency related to gender, but the differences have been significant in cases when related to the year of studies (9). Studies on mental health of students in our environment are still scarce. In case of mental health of students who during their education aim towards heath vocation, number of studies is also low and they mainly refer to future medical doctors. Studies in Serbia point out high level of stress among medical students (10).

The objective of this research was to determine factors related to depression, anxiety and stress, as well as presence of these symptoms among nurses/technicians, professional studies students.

\section{METHODS}

The research was conducted as a cross-sectional study on an appropriate sample of students from the High Medical School of Professional Studies in Belgrade during the month of May 2015. These students did not take part in the examination term so thus the influence of the exam term anxiety to the students' answers was eliminated. The sample consisted of 535 students of both genders, between 18 and 56 years of age, from all three years of studies (total number of students in the High Medical School of Professional Studies for the school year 2014/2015 was $2,784)$. The research was anonymous, based on voluntary participation of students with the guaranteed secrecy of the collected data, without any economic or other gain.

For the purpose of assessment of depression, anxiety and stress symptoms, the Depression, Anxiety and Stress Scale DASS - 42 was used (Lovibond \& Lovibond, 1995) (11). This instrument was developed in accordance with a dominant theoretical point of view on the structure and nature of unpleasant emotional states which was formulated as a Tripartite model. According to the Tripartite model, a negative affect (general distress) is a common characteristic of depression and anxiety, which was confirmed through research (12). According to this model, apart from negative affect as a common factor, there are also factors which are specific for anxiety and depression and which divide them. For anxiety that is somatic tension, i.e. increased physiologic excitement, and for depression that is a low positive affect. The instrument includes three subscales: Depression, Anxiety and Stress. Each of these subscales has 14 items, the responses are in the range from 0 to 3 , and in its total score it has minimum 0 and maximum 42 points for each separate subscale. This self-assessing instrument documents different symptoms of depression, anxiety and stress which the person has suffered during the previous week. The research point out that DASS scales have sufficient reliability, with internal consistence within the range from .80 to .95 (13).

The questionnaire on personal data prepared for the purpose of this research contained information on gender, age, marital status, employment status, years of service, accommodation during studies, year of studies, failure of the study year, importance of an exam mark, number of failed exams, satisfaction with the self as a student and motives of enrollment in the school.

Description of numerical data was performed through classical methods of descriptive statistics i.e. through arithmetic mean and middle value median, and in terms of variability measures, standard deviation, variation coefficient and standard error were used as well as 
minimal and maximal values. Relative numbers were used in all tables. Numerical variables distribution was checked by the Kolmogorov Smirnov test. For variables which had normal distribution, parameter methods were used in further analysis. In the results analysis, depending on the nature of variables, the Pearson chi test was used in the form of homogeneity tests and contingency tables for comparison of differences between frequencies with nonparametric characteristics for both one and two characteristics. For comparison of average parametric characteristics the Student t test was used for two groups of data. As nonparametric additions with independent samples the Mann-Whitney U-test was used and with dependent samples the Wilcoxon signed-rank test was used. For our characteristics relation, analysis methods of one-fold parametric correlation and regression were used, as well as nonparametric correlation depending on data distribution. In all the applied analytic methods the level of significance was 0.05 .

\section{RESULTS}

The study comprised of 535 students, 9 students handed in incomplete questionnaires, so they were excluded from the sample. Response rate was $98.4 \%$. The average age of the students was $23.9 \pm 6.8$, with the range between 18 and 56 years of age. There were 103 male participants (19\%) and 432 female participants (81\%). With regard to their employment structure, 157 (29\%) participants were employed in their vocation, and 378 (71\%) were unemployed. With regard to satisfaction with the self as a student, $2 \%$ of students were dissatisfied, $26 \%$ were partially satisfied and $72 \%$ belonged to the group of satisfied or extremely satisfied students. The Table 1 shows descriptive parameters of numeric characteristics of our participants.

The analysis of depression subscale showed that $6.4 \%$ of participants had slightly expressed depression symptoms (with results in the range between 10 and 13), $4.5 \%$ had medium expressed symptoms (with results in the range between 14 and 20), 1.9\% had strongly expressed symptoms (with results in the range between 21 and 27) and $0.9 \%$ had extremely expressed symptoms (with results in the range between 28 and 42). Analysis of anxiety subscale showed that $8.0 \%$ of participants had slightly expressed depression symptoms (with results in the range between 8 and 9), 8.8\% had medium expressed symptoms (with results in the range between 10 and 14), 4.5\% had strongly expressed symptoms (with results in the range between 15 and 19) and $4.3 \%$ had extremely expressed symptoms (with results in the range between 20 and 42). Analysis of stress subscale showed that $11.4 \%$ of participants had slightly expressed depression symptoms (with results in the range between 15 and 18), 9.7\% had medium expressed symptoms (with results in the range between 19 and 25), 4.3\% had strongly expressed symptoms (with results in the range between 26 and 33) and $0.6 \%$ had extremely expressed symptoms (with results in the range between 34 and 42).

Depression symptoms were significantly related to gender $(\mathrm{p}<0.05)$, employment status $\left(\chi^{2}=11.077\right.$; $\mathrm{p}<$ $0.01)$, total years of service $(p=0.049)$, place of residence $(p=0.012)$, and feeling of satisfaction with the self as a student $(p=0.000)$. There was not a significant correlation between depression symptoms and years of age $(p=$ $0.840)$, marital status $(p=0.663)$, year of studies, failure of the study year, importance of marks, total number of failed exams and motives for enrollment.

Anxiety symptoms were significantly related to gender $(\mathrm{p}=0.001)$, employment status $\left(\chi^{2}=10.354 ; \mathrm{p}<0.01\right)$, total years of service $(\mathrm{p}=0.051)$, and feeling of satisfaction with the self as a student $(p=0.021)$. There was not a significant correlation between anxiety symptoms and years of age $(\mathrm{p}=0.789)$, marital status $(\mathrm{p}=$ $0.852)$, place of residence $(\mathrm{p}=0.453)$, year of studies, failure of the study year, importance of marks, total number of failed exams and motives for enrollment.

Table 1. Descriptive parameters of the participants' numeric characteristics

\begin{tabular}{|c|c|c|c|c|c|}
\hline Numeric characteristics & $\mathbf{n}$ & minimum & maximum & average & SD \\
\hline Age & 535 & 19.00 & 56.00 & 23.9533 & 6.80849 \\
\hline TYS in the field & 535 & .00 & 36.00 & 2.8280 & 6.00471 \\
\hline DASS-stress & 535 & .00 & 42.00 & 10.7084 & 7.50711 \\
\hline DASS-anxiety & 535 & .00 & 38.00 & 5.7084 & 5.96377 \\
\hline DASS-depression & 535 & .00 & 40.00 & 4.7570 & 5.76058 \\
\hline Valid N (listwise) & 535 & & & & \\
\hline
\end{tabular}

TYS - total years of service; SD - standard deviation; 
Stress symptoms were significantly related to gender $(p=0.001)$, employment status $\left(\chi^{2}=8.704 ; p<0.05\right)$, total years of service $(p=0.017)$, feeling of satisfaction with the self as a student $(\mathrm{p}=0.004)$ and motives for enrollment $(\mathrm{F}=6.445 ; \mathrm{p}<0.05)$. There was not a significant correlation between stress symptoms and years of age $(\mathrm{p}=$ $0.543)$, marital status $(p=0.633)$, place of residence $(p=$ 0.616), year of studies, failure of the study year, importance of marks and total number of failed exams. Descriptive parameters for numeric characteristics related to gender are given in the Table 2. Statistical significance and the test values for the compared parameters of numeric characteristics related to gender are given in the Table 3 .

Both the test and nonparametric check (due to high SD values) confirmed that average values of all three examined scales were statistically highly different in relation to the employment status, with higher average values of the examined scales found among employed participants. The largest difference in favor of the

Table 2. Descriptive parameters for numeric characteristics related to gender

\begin{tabular}{|l|c|c|c|c|c|}
\hline Characteristics & Gender & $\mathbf{n}$ & average & SD & SE \\
\hline \multirow{2}{*}{ DASS- } & male & 103 & 8.534 & 7.378 & 0.727 \\
\cline { 2 - 6 } & female & 432 & 11.226 & 7.452 & 0.358 \\
\hline \multirow{2}{*}{ DASS- } & male & 103 & 3.902 & 4.733 & 0.466 \\
\cline { 2 - 6 } & female & 432 & 6.138 & 6.148 & 0.465 \\
\hline \multirow{2}{*}{ DASS- } & male & 103 & 3.572 & 4.724 & 0.286 \\
\cline { 2 - 6 }
\end{tabular}

SD - standard deviation; SE - standard error

Table 3 Test values and significance for scales parameters related to gender

\begin{tabular}{|l|c|c|c|}
\hline \multirow{2}{*}{\multicolumn{2}{c|}{ Characteristics }} & \multicolumn{2}{|c|}{ t-test } \\
\cline { 2 - 4 } & t & df & $0.001^{* *}$ \\
\hline DASS-stress & 3.302 & 533 & $0.001^{* *}$ \\
\hline DASS-anxiety & 3.454 & 533 & $0.020^{*}$ \\
\hline DASS-depression & 2.331 & 533 & \\
\hline
\end{tabular}

$* \mathrm{p}<0.05 ; * * \mathrm{p}<0.01-$ statistical significance

Table 4. Descriptive parameters for numeric characteristics related to employment status

\begin{tabular}{|l|c|c|c|c|c|}
\hline Characteristic & Are you employed & $\mathbf{n}$ & average & SD & SE \\
\hline DASS- & Yes & 157 & 12.127 & 7.644 & 0.610 \\
\cline { 2 - 6 } Stress & No & 378 & 10.119 & 7.379 & 0.379 \\
\hline DASS- & Yes & 157 & 6.636 & 5.995 & 0.478 \\
\cline { 2 - 6 } Anxiety & No & 378 & 5.322 & 5.915 & 0.304 \\
\hline DASS- & Yes & 157 & 5.796 & 6.068 & 0.484 \\
\cline { 2 - 6 } Depression & No & 378 & 4.325 & 5.579 & 0.286 \\
\hline
\end{tabular}

SD - standard deviation; SE - standard error 
employed was stated with the stress scale values, and the lowest with anxiety scale, i.e. its values, though all of them were statistically significant. Descriptive parameters for numeric characteristics related to employment status are shown in the Table 4. Statistical significance and test values for the compared numeric characteristics parameters related to $\mathrm{n}$ status are shown in the Table 5 .

Both the ANOVA test (variance analysis) and nonparametric check (due to high SD values) confirmed that average values for all three examined scales were statistically significantly different in relation with TYS in the vocation, divided in four gradations. DASS - stress scale had the highest average values with participants who had worked from 1 to 10 years and after that the values of the scale were gradually decreasing with longer periods of service. Identical situation was with other DASS - anxiety and DASS - depression scales, their average values were not the lowest with the unemployed, but with those who

Table 5. Test values and significance for scale parameters related to employment status

\begin{tabular}{|l|c|c|c|}
\hline \multirow{2}{*}{\multicolumn{1}{c|}{ Characteristic }} & \multicolumn{2}{|c|}{ t-test } \\
\cline { 2 - 4 } & t & df & $0.005^{* *}$ \\
\hline DASS-stress & 2.836 & 533 & $0.020^{* *}$ \\
\hline DASS-anxiety & 2.331 & 533 & $0.007^{* *}$ \\
\hline DASS-depression & 2.705 & 533 & \\
\hline
\end{tabular}

$* \mathrm{p}<0.05 ; * * \mathrm{p}<0.01-$ statistical significance

Table 6. Descriptive parameters for numeric characteristics related to TYS

\begin{tabular}{|c|c|c|c|c|c|}
\hline Characteristics & TYS & $\mathbf{N}$ & Average & SD & SE \\
\hline \multirow{5}{*}{$\begin{array}{l}\text { DAS- } \\
\text { Stress }\end{array}$} & 0 & 378 & 10.2222 & 7.37501 & .37933 \\
\hline & $1-10$ & 102 & 12.8333 & 8.57244 & .84880 \\
\hline & $11-20$ & 43 & 10.1860 & 5.44783 & .83079 \\
\hline & 20 and above & 12 & 9.8333 & 5.63807 & 1.62757 \\
\hline & Total & 535 & 10.7084 & 7.50711 & .32456 \\
\hline \multirow{5}{*}{ DASS-anxiety } & 0 & 378 & 5.3466 & 5.89600 & .30326 \\
\hline & $1-10$ & 102 & 7.1863 & 6.86609 & .67984 \\
\hline & $11-20$ & 43 & 5.4186 & 3.97751 & .60656 \\
\hline & 20 and above & 12 & 5.5833 & 4.10007 & 1.18359 \\
\hline & Total & 535 & 5.7084 & 5.96377 & .25784 \\
\hline \multirow{5}{*}{$\begin{array}{l}\text { DASS- } \\
\text { Depression }\end{array}$} & 0 & 378 & 4.3730 & 5.64098 & .29014 \\
\hline & $1-10$ & 102 & 5.9510 & 6.60090 & .65359 \\
\hline & $11-20$ & 43 & 5.0233 & 3.78901 & .57782 \\
\hline & 20 and above & 12 & 5.7500 & 6.77059 & 1.95450 \\
\hline & Total & 535 & 4.7570 & 5.76058 & .24905 \\
\hline
\end{tabular}

TYS - total years of service; SD - standard deviation; SE - standard error 
Table 7. Test results and significance for scales parameters related to satisfaction with the self as a student

\begin{tabular}{|l|c|c|}
\hline Characteristics & F & p \\
\hline DASS-stress & 4.565 & $0.004^{* *}$ \\
\hline DASS-anxiety & 3.287 & $0.021^{*}$ \\
\hline DASS-depression & 8.257 & $0.000^{* *}$ \\
\hline
\end{tabular}

$* \mathrm{p}<0.05 ; * * \mathrm{p}<0.01-$ statistical significance

had been working between 11 and 20 years. Descriptive parameters for numeric characteristics related to total years of service are shown in the Table 6.

Average values of all examined scales are statistically significantly different in comparison with the level of the participants' satisfaction divided in four gradations. Depression level according to DASS scale was averagely the highest in the group of participants who were dissatisfied and closely similar and at the same time lower with satisfied and extremely satisfied persons. Stress level according to DASS scale was on average the highest in the group of participants who were dissatisfied and closely similar and at the same time lower with satisfied and extremely satisfied persons. Anxiety level according to DASS scale was on average the highest in the group of participants who were partially satisfied and dissatisfied and closely similar and at the same time lower with satisfied and extremely satisfied persons. The results of the test for scales parameters related to satisfaction with the self as a student are shown in the Table 7.

\section{DISCUSSION}

The results of our study point out that depression, anxiety and stress research, as well as research on factors that are related to them is an important question among nurses, professional studies students, having in mind that nurses are almost half of total number of all employees in health care system.

The results of our study have shown that $13.6 \%$ of students have depression symptoms and 25.6\% have anxiety symptoms. Also, $26.0 \%$ of students have stress score values above the threshold values that are graded from slightly to extremely expressing symptoms. These results are significantly lower in comparison with the results obtained from the research on depression symptoms presence with medical care students in Taiwan (32.6\%) (14), Teheran (38.7\%) (15), Hong Kong (35.8\%) (16) and Sri Lanka (51.1\%) (6). Also, presence of anxiety and stress symptoms with our students is much lower in comparison with research conducted among the same population in the countries of Asian continent $(6,16)$. These differences to some extent can be explained by intercultural differences as well as differences in health care system organization, applied instruments and size of the sample.

Our study shows statistically significant differences in depression, anxiety and stress symptoms presence among students who are employed in medical care system and the unemployed. The anxiety subscale showed higher presence of employed participants that had slight or medium anxiety in relation to the unemployed $(21.7 \%$ to $14.8 \%$ ). The share of employed participants who had slightly or strongly expressed symptoms of depression in relation to the unemployed was $(13.4 \%$ to $6.1 \%)$. The ratio of employed participants that had slightly, medium or strongly expressed symptoms of stress in relation to the unemployed was (33.2\% to $22.2 \%$ ). Having in mind such results, it would be important to examine which organizational factors in the group of employed nurses represent predictors of depression, anxiety and stress. As the strongest stressors in the group of organizational factors at nurses' work place are work: overload, administrative tasks increase, inadequate salary, shortage of workforce (17), shift work, inability to make decisions and inadequate social support (18).

Female participants in our study are significantly more present in slightly, medium, strongly and extremely strongly expressed symptoms at all three examined subscales. For depression the ratio was $14.9 \%$ to $8.8 \%$ ), for anxiety $(27.3 \%$ to $18.4 \%)$ and for stress $(27.3 \%$ to $20.4 \%$ ). These results are in accordance with some research from this field 8 and they can be connected to deeper emotional investments in problems which can arise during work with patients, colleagues and within work process itself11. Also, women are more exposed to influence of different stressing factors because in contemporary life and work conditions they are assigned with numerous roles which were imposed on them through history (19).

With reference to total years of service, the highest average values for depression, anxiety and stress were noticed with participants who had up to 10 years of service, and the lowest values for all three entities were not the lowest with the unemployed, but with those who had been working from 11 to 20 years. Participants who have up to 10 years of service belong to so called 
beginners in work due to the fact that in our sample a large number of persons had been working for one, two or three years. Their significantly higher level of stress can be related to their feeling of competence in their work, having in mind the fact that competence should be acquired through work experience, skills development, knowledge and skills that lead towards successful work results (20). Unlike their younger colleagues, nurses who had been working from 11 to 20 years in accordance with their age had enough time to take up stable positions both within their professional role and in their family milieu. Stable external relations, professional and marital stability are important components of mental health.

Score analysis on depression scale in relation to the place of residence of our participants has shown that the highest average values of depression have been noted with students who had their own flats. Having in mind the fact that the participant who were living with their parents, who were renting a flat or who were living in campuses had significantly lower scores on depression scale, it would be important to examine influence of credit burden on mental health problems, having in mind the fact that financial credit burden is considered a significant predictor of depression in student population (21).

Analysis of average depression, anxiety and stress values in relation to personal feeling of satisfaction with the self as a student has shown that average values for all three entities examined through four gradations, ranging from dissatisfied to extremely satisfied were the highest with participants who were dissatisfied with the self as a student. This result is in accordance with understanding of personal wellbeing from the aspect of positive psychology which under the term personal wellbeing understands high level of positive and low level of negative affect as well as high level of satisfaction with the self in personal life (22).

The analysis has shown that there were no statistically significant differences in average values of depression and anxiety scales in relation to motives for enrollment in the High Medical School of Professional Studies, except on the stress subscale. Average stress values at DASS scale were the highest with participants whose motive was to secure a work position for themselves, and the lowest with those whose motive was promotion in their profession. This result could be compared with Maslow's hierarchy of motives which points out that some higher need cannot appear until some lower need is satisfied (23). Having in mind the fact that certainty in terms of work position and employment on open term basis are primary and basic need of each employed person, we can assume that our nurses who are struggle to keep their jobs with constant expectation of employment contract expiry are experiencing the highest level of stress.

This study is one of the first observational studies in our country with the subject of mental health of nurses/technicians, professional studies students, but also it is important to point out that it has had a couple of limitations. The data on independent and dependent variables were obtained through self-assessment tests, without behaviour observation. The sample consisted of participants from only one High Medical School of Professional Studies from the territory of Belgrade. However, even beside the limitations, the results are important because they show connection of certain sociodemographic characteristics with mental health problems.

\section{CONCLUSION}

According to our research, the following important factors connected to depression, anxiety and stress with nurses, professional studies students, can be pointed out: employment status, gender, years of service, place of residence, personal feeling of satisfaction with the self as a student and motives for enrollment.

The results of the study confirm the importance of early recognition of metal health problems with nurses/technicians with the aim of chronicity decreasing and personal wellbeing increase, both for medical services providers and for their users.

\section{ABBREVIATIONS:}

DASS - depression, anxiety and stress scale

TYS - total years of service

SD - standard deviation

$\mathrm{SE}$ - standard error

\section{REFERENCES}

1. Expert Group on Youth Development and Health of the Ministry of Health of Serbia. Strategy for youth development and health in the Republic of Serbia. Belgrade: Ministry of Health of the Republic of Serbia 2006.

2. Merikangas K, Nakamura E, Kessler R. Epidemiology of mental disorders in children and adolescents. Dialogues Clin Neurosci 2009; 11: 7-20.

3. Bayram N, Bilgel N. The prevalence and sociodemographic correlations of depression, anxiety and stress among a group of university students. Soc Psychiatry Epidemiol 2008; 43: 667-72.

4. Rezayat F, Dehghan NN. The level of depression and assertiveness among nursing students. Int $\mathrm{J}$ Community Based Nurs Midwifery 2014; 2:177-84.

5. Chernomas WM, Shapiro C. Stress, Depression, and Anxiety among Undergraduate Nursing Students. International Journal of Nursing Education Scholarship 2013; 10: 1-12. 
6. Rathnayake S, Ekanayaka J. Depression, anxiety and stress among undergraduate nursing students in a Public University in Sri Lanka. International Journal of Caring Sciences 2016; 9: 1020-32.

7. Akhu-Zaheya LM, Shaban IA, Khater WA. Nursing students' perceived stress and influences in clinical performance. International Journal of Advanced Nursing Studies 2015; 4: 44-8.

8. Atindanbila S, Abasimi E, Anim MT. A study of work related depression, anxiety and stress of nurses at Pantang Hospital in Ghana. Research on Humanities and Social Sciences 2012; 2: 5.

9. Papazisis G, Tsiga E, Papanikolaou N, Vlasiadis I, Sapountzi-Krepia D. Psychological distress anxiety and depression among nursing students in Greece. International Journal of Caring Sciences 2008; 1: 42-6.

10. Lečić-Toševski D, Draganić-Gajić S, PejovićMilovančević M, Kostić M, Vuković O. Problemi mentalnog zdravlja kod studenata medicine u Srbiji izazovi i perspective. Psihijatrija danas 2014; 46: 17386.

11. Lovibond SH, Lovibond PF. Manual for the Depression Anxiety Stress Scales. (2nd. Ed.) Sydney: Psychology Foundation; 1995.

12. Brown TA, Chorpita BF, Korotitsch W, Barlow DH. Psychometric properties of the Depression Anxiety Stress Scales (DASS) in clinical samples. Behaviour Research and Therapy 1997; 35: 79-89.

13. Nieuwenhuijsen K, Boer AGEM, Verbeek JHAM, Blonk RWB, Van Dijk FJH. The depression anxiety stress scales (DASS): detecting anxiety disorder and depression in employees absent from work because of mental health problems. Occup Environ Med 2003; 60: i77-i82.

14. Chen CJ, Chen YC, Sung HC, Hsieh TC, Lee MS, Chang CY. The prevalence and related factors of depressive symptoms among junior college nursing students: a cross-sectional study. Journal of Psychiatric and Mental Health Nursing 2015; 22: 590-8.
15. Rezayat F, Nayeri ND. The level of depression and assertiveness among nursing students. International Journal of Community Based Nurs Midwifery 2014; 2: 177-84.

16. Cheung T, Yip P. Depression, anxiety and symptoms of stress among Baccalaureate nursing students in Hong Kong: A Cross Sectional Study. International Journal of Environmental Research and Public Health 2016; 13: 779 .

17. Gazivoda A. Stres na random mjestu medicinskih sestara i tehničara, neobjavljeni diplomski rad. Zagreb: odjel za psihologiju Hrvatskih studija, 2015.

18. Zavalić M. Svjetski trendovi u zaštiti zdravlja na radu. Sigurnost 2014; 56: 323-9.

19. Zaher JS, Vafaei M, Abianeh EE. Comparing depression, anxiety and stress among the Nurses in the critical care and internal surgical units at the selected hospitals of the Social Security Organization of Tehran in 2016. International Journal of Medical Research \& Health Sciences 2016; 5: 254-61.

20. Vujić D. Kompetencije-odgovor na nove izazove upravljanja ljudskim resursima. Druga međunarodna naučna konferencija pod nazivom Synthesis, Univerzitet Singidunum u Beogradu, 2015, preuzeto sa: http://jiws.rs/wp-content/uploads/2016/03/TEKSTSYNTEZIS-PREMA-UPUTSTVU-k.pdf

21. Lee RB, Maria MS, Estanislao S, Rodriquez C. Factors associated with higher levels of depressive symptoms among international University students in the Philippines. Southeast Asian J Trop Med Public Health 2013; 44: 1098-107.

22. Vukomanović SI. Procena mentalnog zdravlja i prevencija mentalnih poremećaja studentske populacije, doktorska disertacija, Univerzitet $\mathrm{u}$ Kragujevcu, 2015.

23. Tijanić M, Đuranović D, Rudić R, Milović Lj. Zdravstvena nega i savremeno sestrinstvo. Beograd: Naučna KMD, 2001. 